\title{
Debt Sustainability: Can EU Member States Use Environmental Taxes to Regain Fiscal Space?
}

\author{
Ioana-Laura Țibulcă
}

check for updates

Citation: Tibulcă, I.-L. Debt

Sustainability: Can EU Member States Use Environmental Taxes to Regain Fiscal Space?. Sustainability 2021, 13, 5952. https://doi.org/ $10.3390 /$ su13115952

Academic Editor:

Elena Fernández-Rodríguez

Received: 26 April 2021

Accepted: 22 May 2021

Published: 25 May 2021

Publisher's Note: MDPI stays neutral with regard to jurisdictional claims in published maps and institutional affiliations.

Copyright: (C) 2021 by the author. Licensee MDPI, Basel, Switzerland. This article is an open access article distributed under the terms and conditions of the Creative Commons Attribution (CC BY) license (https:// creativecommons.org/licenses/by/ $4.0 /)$.
Department of Finance and Center of Financial and Monetary Research (CEFIMO), Bucharest University of Economic Studies, 010961 Bucharest, Romania; ioana.tibulca@fin.ase.ro; Tel.: +40-021-319-19-00

\begin{abstract}
The COVID-19 pandemic has taken its toll on the economies of the EU member states. While policymakers have been faced with rising government spending in an effort to combat the health crisis, this has led to unprecedented levels of government debt and budget deficits. Debt sustainability has been severely affected by decreasing fiscal space, and there are significant concerns that a debt crisis is looming on the horizon for the EU. The current study aims to analyze environmental taxes as a potential solution for rebuilding fiscal space and thus improving debt sustainability in the EU. The research method used to study the impact that the four types of environmental taxes may have on fiscal space is the dynamic panel regression model, estimated using the Generalized Method of Moments (GMM). The conclusions show that all four categories of environmental taxes can help the EU member states regain fiscal space and improve their debt sustainability. The research results show that the strongest positive impact on fiscal space will be achieved by energy taxes and transport taxes.
\end{abstract}

Keywords: fiscal space; environmental taxes; debt sustainability; climate-friendly fiscal policy

\section{Introduction}

Environmental taxes are defined, according to Regulation (EU) N 691/2011, as taxes whose tax base is a physical unit of an item that has a proven and specific negative impact on the environment. Eurostat provides not only data on environmental taxes in the EU but also further clarifications on exactly what can be included in the category of environmental taxes. According to Eurostat's 2013 'Environmental taxes-a statistical guide' there are four main types of environmental taxes: energy taxes, pollution taxes, resource taxes and transport taxes.

Energy taxes include taxes on the production of energy as well as energy products (petrol, diesel, natural gas, coal, and electricity). This category also includes carbon dioxide $\left(\mathrm{CO}_{2}\right)$ taxes; however, if a country uses these, they need to be reported separately. Taxes on greenhouse gases are also included under energy taxes, not under pollution taxes. Revenue generated from the selling of emissions permits are also included in this category.

Pollution taxes include levies on air emissions and water emissions as well as the management of solid waste and taxes related to the level of noise. Resource taxes are those applicable to the extraction and use of depletable natural resources such as water, forests, plant life, and wild animals. Taxes on the ownership of land are not considered resource taxes, but many countries apply taxes for the conversion of landscapes (such as deforestation), and these are considered to be resource taxes.

Transport taxes are those linked to the ownership and use of any means of transport (or motor vehicle). These taxes also apply to planes, ships, and railways. Perhaps more surprising is the fact that transport taxes include even means of transport that are regarded as being environmentally friendly, such as electric cars. In addition, the taxes that some cities have implemented to restrict the access of vehicles to the city center are also considered transport taxes. However, the taxes that apply to fuel for transport (petrol and diesel, for instance) are not transport taxes, but energy taxes. 
In 2019, the total revenue collected from environmental taxes across the EU was 330.6 billion EUR, which represents $2.4 \%$ of the EU gross domestic product (GDP). Most of this came from energy taxes $(77.9 \%)$, with taxes on transport second $(18.9 \%)$, followed by taxes on pollution and resources $(3.2 \%)$. A more detailed structure of environmental taxes for each member state of the EU can be seen in Figure 1. The environmental tax burden was shared almost equally between corporations and households. On average, in the EU, the revenue from environmental taxes represents $6 \%$ of all revenue from taxes and social contributions, with individual member state's percentages varying from 10.3\% in Bulgaria to $4.4 \%$ in Germany and Luxembourg [1].

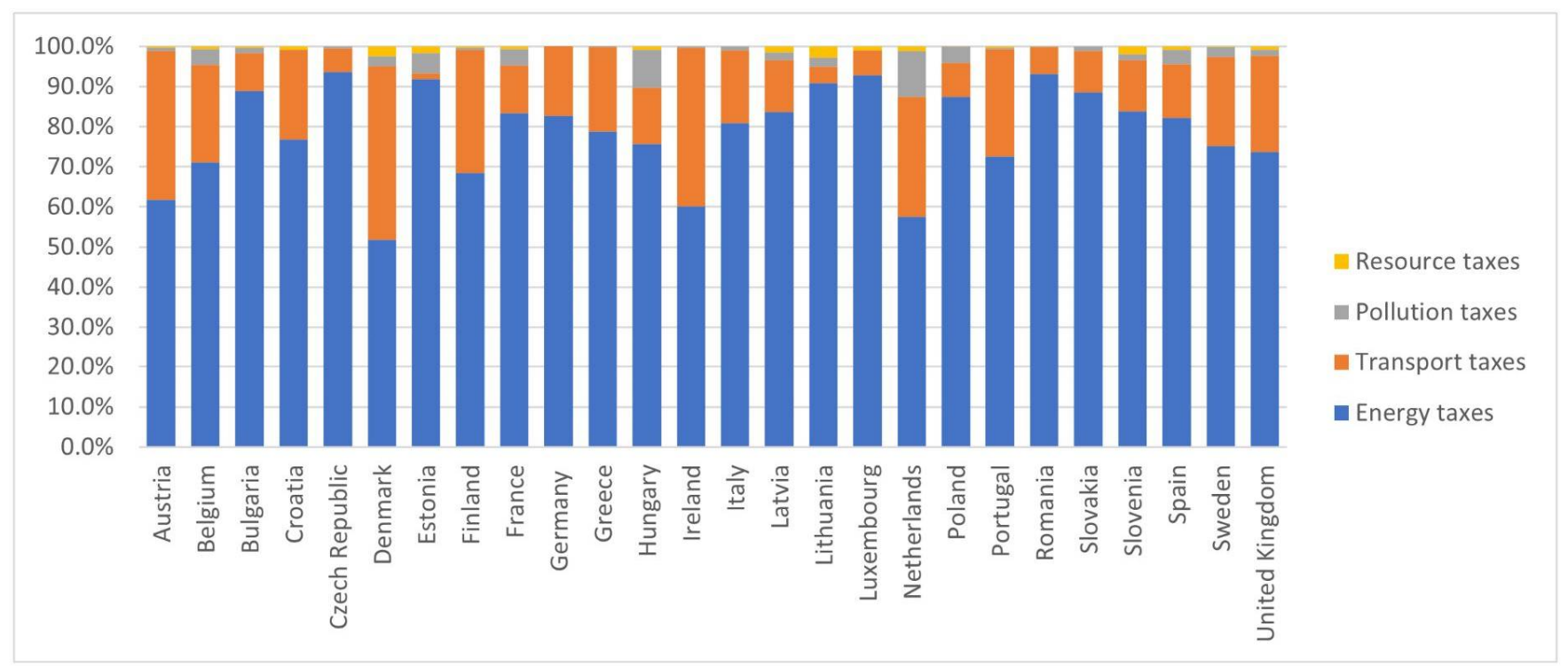

Figure 1. Structure of environmental taxes by category (2019).

Achieving climate neutrality by 2050 is the official environmental policy goal of the European Union. However, environmental concerns have taken a back seat since the beginning of the COVID-19 pandemic, as policymakers have been forced to focus their decisions on dealing with the social and economic effects of this health crisis. Governments across Europe have raised their spending on healthcare and social security measures, tax collection deadlines have been postponed in an effort to keep business alive during lockdown periods, and public borrowing has increased to unprecedented levels. All this has led to diminished fiscal space and growing concerns about a debt crisis looming on the horizon for the EU member states.

In 2020, all the EU member states are expecting budget deficits to be above the $3 \%$ of the GDP limit previously set and rigorously enforced by the European Commission. Therefore, deficit reduction policies are expected to follow. Existing research shows the disadvantages of both expenditure-based and tax-based austerity plans, with the biggest threat being the potential of a long-lasting recession [2]. Consequently, a different approach seems to be needed.

The current research aims to look at environmental taxes as a potential solution for the EU member states to regain fiscal space while also achieving the environmental policy objectives established before the onset of the pandemic.

\section{Literature Review}

Environmental taxes have been the focus of several research directions in the past two decades. Some studies focus on providing an overview of environmental taxes in the EU [3]. In 2001, Newbery [4] published a study looking at the variety of road transport fuel taxes in the EU, with the aim of providing arguments in favor of harmonizing fuel taxes. In 2003, Sterner and Köhlin [5] talked about the high levels of environmental taxes in the 
EU compared to the US and the diversity of issues regarding these taxes within the EU. Other studies focus on comparative statistical analysis and provide detailed individual overviews of the types of environmental taxes and excise duties used by each EU member state [6].

More recent research focuses on the sustainability issues related to environmental taxes in the EU. Though more than 500 different policy instruments have been identified in the EU to address environmental issues, it is still a challenge to integrate environmental concerns across all areas of EU policymaking [7]. While the main goal of environmental taxes is still reducing pollution and the use of depletable resources, their fiscal functions and benefits are also acknowledged. Environmental taxes can help achieve a "holistic, all-inclusive policy approach" [8]. In addition, these taxes have several other benefits: they are not as distorting to economic behavior as labor or corporate taxes, administrative costs are lower than for income taxes or consumption taxes, and evasion is also lower [9-11]. The current study is focused on analyzing yet another benefit of environmental taxes-their potential to improve a country's fiscal space.

The efficiency of environmental taxes has come under scrutiny repeatedly as increasing environmental protection concerns have again put the spotlight on green taxation. Borozan [12] published a study on energy taxes in the EU, and after conducting an analysis based on system generalized method of moments, the author concluded that this category of environmental taxes has a long-run, indirect impact on electricity consumption through energy prices. In 2017, Moutinho et al. [13] used Data Envelopment Analysis to evaluate the environmental efficiency of $26 \mathrm{EU}$ member states and suggested policy measures to improve the efficiency of each type of environmental taxes.

Other studies focus on improving consumers' awareness of environmental concerns as a means of promoting green products and adding to the efficiency of environmental taxes [14] or the need for stricter regional government policies to increase the effectiveness of environmental taxes in combating pollution [15]. Since the EU member states have been trying to decrease air pollution levels and, in particular, $\mathrm{CO}_{2}$ emissions, recent studies have focused on assessing the effectiveness of green taxes as incentives in promoting the use of environmentally friendly cars [16-18]. In the current study, environmental tax efficiency will be approached from a different perspective: that of increasing a country's fiscal space.

Climate change is seen as a factor that negatively impacts the financial stability of an economy $[19,20]$. On the flip side, fiscal policy has a clear role in climate-change adaptation, though research reveals that preventive measures are much more effective than waiting until there is a need for corrective measures [21]. Even if climate change cannot be solely attributed to pollution, this is one of the concerns that fiscal policy, mainly through environmental taxes, is trying to address.

Fiscal space has been linked to both fiscal stability [22,23] and debt sustainability [24]. According to Estevão [25], implementing climate-friendly fiscal policy measures would improve debt sustainability and help expand a country's fiscal space. However, research linking environmental taxes and an economy's fiscal space is lacking. The current study aims to help fill this current gap in the literature by analyzing environmental taxes as a potential solution to improving fiscal space for EU member states. This is particularly important in the current context, where government debts have increased due to efforts to combat the COVID-19 pandemic, and a debt crisis seems to be a real concern for most European countries.

Some definitions of fiscal space refer to the government's ability to borrow funds without jeopardizing fiscal sustainability [26,27], while other definitions consider fiscal space to be the available government financing due to policies and reforms that enhance economic and institutional development [28]. Fiscal space is further defined as the distance between the actual debt and a debt limit beyond which the level of government debt would be unsustainable and would require extraordinary measures $[29,30]$.

There is no single indicator to measure fiscal space, and consequently different authors have proposed a variety of methodologies for determining fiscal space. Several studies 
focused on using the ability to achieve long-term sustainability [31] or the loss of market access $[30,32]$, but these seemingly different approaches were later considered closely related from a practical standpoint [33]. Other studies have managed to measure fiscal space by using a "prudent level of debt", determined with the help of a probabilistic approach [34,35]. In a study published in 2012 [36], fiscal space was determined as the difference between the maximum tax revenue achievable (the peak of the Laffer curve) and the actual tax revenue. A year later, Mario [37] calculated fiscal space as the necessary fiscal adjustment for a country to reach a debt level of $60 \%$ of GDP by 2030 .

Aizenman and Jinjarak [38] propose an indicator called "De Facto Fiscal Space", which they calculate as the number of years necessary for a country to repay its debt using its tax revenue. This indicator is used in later studies to analyze the relationship between fiscal space and other macroeconomic indicators such as government spending [39], openness to international trade [40], and level of tax reform in developing countries [41]. An additional indicator for fiscal space is calculated by Yohou [42] using the non-parametric mathematical programming approach of Data Envelopment Analysis (DEA) to estimate efficiency scores for public spending. In this approach, the author assesses the quality of public spending, considering the structure as well as the efficiency of public spending. The goal is to calculate the extra fiscal room that countries can use to achieve economic development.

Though all of these approaches to measuring fiscal space have their advantages, they still fail to take into consideration some significant variables that influence fiscal sustainability. This is one gap in the existing literature that the current study aims to help close. Additionally, some of the previous approaches to measuring fiscal space look to simplify the complexity of the economic environment by considering a closed economy. Furthermore, they do not consider the maturity of the public debt or other country-specific effects [33]. This is another gap in the currently available research that the current study aims to fill.

All in all, the contribution of the current paper is threefold: (i) first, this research aims to fill a gap in the existing literature regarding the potential impact of environmental taxes on fiscal space in an economy; (ii) second, a new approach to determining the fiscal space is used, which aims to eliminate some of the shortcomings of previous approaches by considering several indicators that influence fiscal space (including debt maturity); (iii) third, each of the four types of environmental taxes is analyzed separately, and countryspecific elements such as governmental approach to environmental issues and government effectiveness are also included in the analysis.

\section{Materials and Methods}

This section consists of two subsections. The first one is dedicated to explaining the approach used to determine fiscal space for each country included in the analysis. The second subsection is dedicated to describing the data and estimation method used for the study of the influence of environmental taxes on fiscal space.

\subsection{Fiscal Space}

Given the shortcomings of the existing literature in determining fiscal space, the current study proposes a different approach, which uses Principal Components Analysis (PCA) based on three indicators that influence the level and sustainability of public debt: the government's ability to repay public debt, government short-run maturing debt, and the country rating. These indicators are further explained in Table 1 . The choice of indicators for PCA aims to approach fiscal space as both government access to future funding through borrowing and the ability to pay the existing government debt. 
Table 1. Indicators used to determine fiscal space.

\begin{tabular}{ccc}
\hline Indicator (Symbol) & Explanation & Source \\
\hline $\begin{array}{c}\text { Government ability to repay debt (GAD) } \\
\text { Government debt short-run maturity } \\
\text { (DEBTDUE) }\end{array}$ & $\begin{array}{c}\text { General government debt maturing in 12 months or } \\
\text { less * \% of GDP }\end{array}$ & $\begin{array}{c}\text { World Bank website } \\
\text { time period 2011-2019 } \\
\text { World Bank website } \\
\text { time period 2011-2019 } \\
\text { Country rating (SOVRATE) }\end{array}$ \\
$\begin{array}{c}\text { Foreign currency long-term sovereign debt ratings * } \\
\text { index from 1 to 21 }\end{array}$ & $\begin{array}{c}\text { World Bank website } \\
\text { time period 2011-2019 }\end{array}$ \\
\hline
\end{tabular}

Source: Author's compilation. ${ }^{*}$ Data used for variables is part of a World Bank working paper dataset [43].

The source of the data for the indicators used to determine the fiscal space [43] did not include information for Malta, so the study is conducted for only 27 member states of the EU (including the UK) during the time period 2011-2019.

The research method used to determine fiscal space in the current study is Principal Components Analysis (PCA). This is widely used to reduce the size of datasets while minimizing loss of information by creating new indicators (principal components) as a linear combination of the initial variables included in the database [44]. In the current study, the goal is to determine the value of fiscal space by combining the information provided by three indicators: the government's ability to pay its gross debt (GAD), government debt due to be paid in the next year (DEBTDUE), and debt rating (SOVRATE), which shows the perception of international rating agencies regarding the sustainability of the government debt. This final indicator impacts not only a government's access to international funding but also the interest rate at which it will be able to borrow.

Two tests were run previously to applying PCA to ensure that this research method was indeed appropriate for the database described above. The Kaiser-Meyer-Olkin Measure of Sampling Adequacy is a statistic that shows if factor analysis is indeed applicable to a dataset. According to the existing literature [45,46], values above 0.5 indicate an adequate database for PCA. For the current study, Kaiser's MSA was 0.6, which leads to the conclusion that the proposed research method is suitable. Bartlett's test of sphericity has the null hypothesis that the correlation matrix is an identity matrix, which would indicate that our three indicators are unrelated and therefore not suitable for running PCA [47]. For the current database, Bartlett chi-square was 418.8566 and Bartlett probability was 0.0000 , which shows that the null hypothesis should be rejected and applying PCA for the dataset is useful and appropriate.

After running the PCA, the characteristic value of the first principal component extracted was 2.025937. As the value was greater than 1, it can be concluded that this component should be retained. The other two components extracted each had a characteristic value below 1 . Additionally, the cumulative proportion of the first principal component was $67.53 \%$, which shows that most of the information in the original indicators is retained by the first component. Therefore, the first principal component was used to construct a new, comprehensive index of fiscal space. This is shown in Equation (1).

$$
\text { Fiscal_space }=0.636595 \times \text { GAD }-0.602923 \times \text { DEBTDUE }+0.480865 \times \text { SOVRATE }
$$

\subsection{Dynamic Panel Regression Models}

To achieve the goal of answering the main research question of whether environmental taxes can be used to rebuild fiscal space, four dynamic panel regression models were estimated. The explanatory variables included in the models were based on existing literature [41], as is the shape of the models used [48]. An explanation of the variables used is provided in Table 2. This section of the study is based on panel data for the time period 2011-2019 for 27 of the 28 member states of the EU at the time (Malta is not included in the research as information for this country was not available for all the variables). 
Table 2. Variables used in regression models.

\begin{tabular}{|c|c|c|}
\hline Indicator (Symbol) & Explanation & Source \\
\hline Fiscal space (Fiscal_space) & $\begin{array}{l}\text { Indicator showing the sustainability of } \\
\text { government debt }\end{array}$ & $\begin{array}{c}\text { Author's calculations * based on methodology } \\
\text { explained in Section } 3.1 \\
\text { time period 2011-2019 }\end{array}$ \\
\hline Energy taxes (Eng_TAX) & $\begin{array}{l}\text { Environmental taxes on energy production } \\
\text { and energy products, Million euro, Log }\end{array}$ & $\begin{array}{c}\text { Eurostat database_-code ENV_AC_TAXIND2 } \\
\text { time period } 2011-2019\end{array}$ \\
\hline Pollution taxes (Pol_TAX) & $\begin{array}{l}\text { Environmental taxes on air emissions and } \\
\text { water emissions, Million euro, Log }\end{array}$ & $\begin{array}{c}\text { Eurostat database - code ENV_AC_TAXIND2 } \\
\text { time period 2011-2019 }\end{array}$ \\
\hline Resources taxes (Res_TAX) & $\begin{array}{c}\text { Environmental taxes on use of depletable } \\
\text { natural resources, Million euro, Log }\end{array}$ & $\begin{array}{c}\text { Eurostat database_-code ENV_AC_TAXIND2 } \\
\text { time period 2011-2019 }\end{array}$ \\
\hline Transport taxes (Tra_TAX) & $\begin{array}{l}\text { Environmental taxes on ownership and use of } \\
\text { motor vehicles, Million euro, Log }\end{array}$ & $\begin{array}{c}\text { Eurostat database-code ENV_AC_TAXIND2 } \\
\text { time period 2011-2019 }\end{array}$ \\
\hline Primary balance (PBY) & $\begin{array}{c}\text { Government net borrowing excluding interest } \\
\text { payments on consolidated government } \\
\text { liabilities **, \% GDP }\end{array}$ & $\begin{array}{l}\text { World bank website } \\
\text { time period 2011-2019 }\end{array}$ \\
\hline Economic growth (GDPG) & Real Gross Domestic Product growth, \% & $\begin{array}{c}\text { World Bank national accounts data-code } \\
\text { NY.GDP.MKTP.KD.ZG } \\
\text { time period 2011-2019 }\end{array}$ \\
\hline Government debt maturity (AVGLIFE) & $\begin{array}{c}\text { Sovereign debt average maturity }{ }^{* *} \text {, number of } \\
\text { years }\end{array}$ & $\begin{array}{l}\text { World bank website } \\
\text { time period 2011-2019 }\end{array}$ \\
\hline
\end{tabular}

Source: Author's compilation. * Data for this variable can be provided by the author on request. ${ }^{* *}$ Data used for this variable is part of the World Bank working paper dataset [43].

The link between the primary balance and government debt sustainability is well established in the existing literature [49], with emphasis on the existence of a systematic long-term relationship [50] and estimating debt sustainability limits using a primary balance reaction function to increasing levels of debts [32]. The primary balance is included as a control variable in the current research, with the expectation that it will have a positive relationship with the indicator calculated for fiscal space. In other words, the bigger the increase in the primary balance, the more fiscal space a country will have.

The second control variable included in the study is economic growth. The relationship between the percentage change in real GDP and fiscal space is confirmed by the existing research; however, the nature of the relationship seems to still be under debate. While some reports show that more advanced economies (with lower rates of economic growth) have a larger fiscal space [33], studies conducted for individual emerging economies seem to point to an opposing conclusion [51-53]. For the current research, which is conducted for countries that are EU members, the expectation is of a positive relationship between the two indicators.

The last control variable included in the study is the average maturity of the governmental debt, expressed in number of years. The expectation is that it will have a positive impact on fiscal space [54], as the longer a government has until it needs to pay back its debts, the more fiscal space it should have.

The four regression models, which were estimated, are presented in Equations (2)-(5).

Fiscal_space $_{i t}=\alpha_{0}+\alpha_{1}$ Fiscal_space $_{i t-1}+\alpha_{2}$ Eng_TAX $_{i t}+\alpha_{3}$ PBY $_{i t}+\alpha_{4}$ GDPG $_{i t}+\alpha_{5}$ AVGLIFE $_{i t}+\mu_{i}+\varepsilon_{i}$

where subscript letter $i$ represents the country $(i=1,2, \ldots, 27$, representing each of the 27 member states of the EU included in the analysis), subscript letter $t=2012,2013, \ldots 2019$, representing each year of the time period, $\mu_{i}$ allows for country specific effects, and $\varepsilon_{i}$ is the error term. Eng_TAX represents taxes on energy, PBY is the primary balance of payments, GDPG represents economic growth, and AVGLIFE is the sovereign debt average maturity.

Fiscal_space $_{i t}=\beta_{0}+\beta_{1}$ Fiscal_space $_{i t-1}+\beta_{2}$ Pol_TAX $_{i t}+\beta_{3}$ PBY $_{i t}+\beta_{4}$ GDPG $_{i t}+\beta_{5}$ AVGLIFE $_{i t}+\mu_{i}+\varepsilon_{i}$

where Pol_TAX represents environmental pollution taxes.

Fiscal_space $_{i t}=\gamma_{0}+\gamma_{1}$ Fiscal_space $_{i t-1}+\gamma_{2}$ Res_TAX $_{i t}+\gamma_{3}$ PBY $_{i t}+\gamma_{4}$ GDPG $_{i t}+\gamma_{5}$ AVGLIFE $_{i t}+\mu_{i}+\varepsilon_{i}$ 
where Res_TAX represents the third category of environmental taxes: resource taxes.

Fiscal_space $_{i t}=\delta_{0}+\delta_{1}$ Fiscal_space $_{i t-1}+\delta_{2}$ Tra_TAX $_{i t}+\delta_{3}$ PBY $_{i t}+\delta_{4}$ GDPG $_{i t}+\delta_{5}$ AVGLIFE $_{i t}+\mu_{i}+\varepsilon_{i}$

where Tra_TAX represents transport taxes, as the fourth and final category of environmental taxes.

The four regression models were estimated using the Generalized Method of Moments (GMM), first introduced by Arellano and Bond [55] and later enhanced by Arellano and Bover [56] and Blundell and Bond [57]. Since the main purpose of this research is to analyze the potential of the different categories of environmental taxes in helping governments rebuild fiscal space in the EU, panel data is used. GMM was designed for panel data analysis, with the purpose of diminishing the assumptions needed and focusing on a more complex technique, which allows the retention of useful information [58].

GMM estimation is, therefore, appropriate as it uses first-differencing of the model and lagged values of the variables as instruments; this addresses any endogeneity concerns. Moreover, two-step GMM also solves any first order autocorrelation issues that might arise. The Arellano-Bond test for autocorrelation, which is appropriate for linear regression models on panel data using GMM, showed typical autocorrelation patterns in the first order AR (1), as expected, and no autocorrelation in the second order, AR (2). The results were consistent for all for models.

The panel data used in this study consists of a larger number of countries $(27$ member states of the EU) than number of years (data spans the period between 2011 and 2019, which is 9 years). Consequently, the "small T, large N" condition to apply GMM is fulfilled. The data also satisfies other conditions [58,59] for applying GMM: (i) there are explanatory variables that are not strictly exogenous, in the sense that they are possibly correlated with past and current realizations of the error term; (ii) there may be fixed individual effects, which are randomly distributed; (iii) there may be dynamic relationships, which means that the dependent variable depends on its past realizations.

Difference GMM is appropriate for the estimation of the four models shown in Equations (2)-(5), as the GMM estimation for the coefficient corresponding to the lagged value of the dependent variable (fiscal space) in each regression model showed no downward bias compared to the estimations of the same coefficient using ordinary least squares with fixed effects. All the instruments used are internal ones, with lagged values of the regressors included in each of the four models.

\section{Results}

In 2019, most of the EU member states already had significant levels of gross government debt compared to their GDP. The average gross debt was $85.9 \%$ of the GDP for the Euro area countries and $79.2 \%$ for the entire EU. Budget deficits were also high in 2019 for some member states such as Romania (5\%), Hungary (4.3\%), and Spain (4\%). Government responses to the COVID-19 outbreak in 2020 increased government spending and forced most EU member states to borrow funds, further increasing their debt levels. Consequently, all EU member states are expected to have budget deficits of above $3 \%$ in 2020 [60] (above the limit set by the European Commission). All this has led to rapidly diminishing fiscal space for EU member states. With rising concerns about a looming debt crisis in the EU [61,62], the current research aims to analyze a potential solution for regaining fiscal space in the EU-using environmental taxes.

As previously described, four dynamic panel regression models were estimated using GMM, and the results obtained are presented in Table 3. 
Table 3. Estimation results using panel dynamic GMM.

\begin{tabular}{|c|c|c|c|c|}
\hline \multirow{2}{*}{ Explanatory Variables } & \multicolumn{4}{|c|}{ Dependent Variable_Fiscal_Space } \\
\hline & (1) & (2) & (3) & (4) \\
\hline L1_Fiscal_space & $\begin{array}{c}0.639201 * * * \\
(13.68868)\end{array}$ & $\begin{array}{c}0.898625^{* * *} \\
(25.36782)\end{array}$ & $\begin{array}{c}0.825563^{* * *} \\
(38.22794)\end{array}$ & $\begin{array}{c}0.707006^{* * *} \\
(40.41295)\end{array}$ \\
\hline Eng_TAX & $\begin{array}{c}28.69098^{* * *} \\
(3.671508)\end{array}$ & - & - & - \\
\hline Pol_TAX & - & $\begin{array}{c}2.306387 * * \\
(2.179521)\end{array}$ & - & - \\
\hline Res_TAX & - & - & $\begin{array}{c}1.085047 * * \\
(2.343713)\end{array}$ & - \\
\hline Tra_TAX & - & - & - & $\begin{array}{c}22.91528 * * * \\
(10.96174)\end{array}$ \\
\hline PBY & $\begin{array}{c}0.649813^{* * *} \\
(3.563764)\end{array}$ & $\begin{array}{c}1.193667^{* * *} \\
(12.77405)\end{array}$ & $\begin{array}{c}1.110913^{* * *} \\
(28.44412)\end{array}$ & $\begin{array}{c}0.798758^{* * *} \\
(11.61238)\end{array}$ \\
\hline GDPG & $\begin{array}{c}0.273083^{* * *} \\
(5.966684)\end{array}$ & $\begin{array}{c}0.309410^{* * *} \\
(8.972318)\end{array}$ & $\begin{array}{c}0.537402 * * * \\
(31.49956)\end{array}$ & $\begin{array}{c}0.183906^{* * *} \\
(5.815834)\end{array}$ \\
\hline AVGLIFE & $\begin{array}{c}1.941646^{* * *} \\
(6.816397)\end{array}$ & - & - & - \\
\hline No. of instruments & 5 & 4 & 4 & 4 \\
\hline No. of observations & 140 & 152 & 147 & 186 \\
\hline J-statistic & 19.76843 & 15.06774 & 19.41777 & 22.73971 \\
\hline Prob (J-statistic) & 0.286245 & 0.657311 & 0.430346 & 0.476054 \\
\hline
\end{tabular}

Source: Author's calculations using Eviews 11. Note: An explanation of research variables is provided in Table 2; t-statistic values in (). ${ }^{* * *}$ indicates the statistical significance at $1 \%$ level. ${ }^{* *}$ indicates the statistical significance at $5 \%$ level. * indicates the statistical significance at $10 \%$ level.

The coefficients estimated for each type of environmental tax are statistically significant, and the positive value of these coefficients shows a direct effect of environmental taxes on fiscal space. The biggest impact on rebuilding fiscal space can be achieved by using energy taxes and transport taxes, as the values for these coefficients are much higher than those for pollution taxes and resource taxes. These results are in line with the fact that most of the revenue collected from environmental taxes comes from energy taxes and transport taxes. Less than $5 \%$ of the revenues from environmental taxes comes from the other two categories.

However, the research results also show positive, statistically significant coefficients for pollution taxes and resource taxes. This shows a potential for the EU member states to regain fiscal space by either increasing or implementing these types of environmental taxes. Currently, there are three member states (Cyprus, Germany, and Luxembourg) that do not use pollution taxes at all, while Greece only began to implement them in 2018 . Resources taxes are presently not used by five member states of the EU (the Czech Republic, Germany, Greece, Italy, and Slovakia), while Lithuania began implementing them in 2015. These differences in national approaches to environmental fiscal policy account for some of the differences in the number of observations included in the estimation of each of the four econometric models.

The expectations regarding the relationship between the primary balance (PBY) and fiscal space are confirmed by the research results. All four models show positive, statistically significant coefficients, which supports the idea that an increase in the primary balance will lead to an improvement in fiscal space.

Regarding the relationship between economic growth and fiscal space, the research results show positive, significant coefficients. However, their values are quite small, which points to the conclusion that, even though economic growth can increase fiscal space, the effect will not be a very large one. These results are reassuring to some extent, as the EU 
member states are expected to have negative economic growth in 2020 and 2021, according to predictions published by the European Commission, and the current research shows that this will not greatly reduce fiscal space.

The relationship between the average maturity of government debt (AVGLIFE) and fiscal space confirms the research expectations according to the estimation of model 1 . The coefficient is statistically significant and positive, so it may be concluded that the more time a government has to repay its debts, the more fiscal space that will be available. Data for this indicator (AVGLIFE) were not available for some member states (Cyprus, the Czech Republic, Estonia, and Luxembourg), which accounts for the smaller number of observations included in the estimation of model 1.

The J-test $[63,64]$ results are also included in Table 3 . This test is used for over-identifying restrictions. To put it in simple terms, the null hypothesis of this test is that the model is a valid one. Looking at the J-statistic values and at the $p$-values associated with the test, we cannot reject the null hypothesis, which leads to the conclusion that the models are valid.

\section{Discussion}

The research results presented in the previous section show that the EU member states can use environmental taxes, especially energy taxes and transport taxes, to rebuild fiscal space, which was lost as a result of increasing levels of government indebtedness due to efforts to combat the COVID-19 pandemic. Aside from fiscal benefits, increasing environmental taxes brings additional advantages in terms of environmental goals.

Before the pandemic, the European Union had officially announced that its objective in terms of environmental policy was to achieve climate neutrality, including long-term low greenhouse gas emissions, by 2050. According to the existing literature [65-68], green taxation could contribute to achieving climate protection aims such as diminishing pollution and decreasing levels of emissions of greenhouse gases, making fiscal policy measures climate friendly in the EU.

\subsection{National Approaches to Environmental Policy}

However, one major concern that needs to be considered when talking about fiscal and environmental policy in the EU is that each member state has the authority to decide its own approach. This leads to a wide variety of environmental policy measures and the need for a discussion of the research results, considering some country-specific aspects of climate protection actions. Therefore, the research model estimations were redone, taking into account different approaches to environmental policy. The new estimation results are shown in Table 4.

Table 4. GMM estimation results for EU member states with different levels of government spending on the environment.

\begin{tabular}{|c|c|c|c|c|}
\hline \multirow{3}{*}{ Explanatory Variables } & \multicolumn{4}{|c|}{ High Government Spending on the Environment } \\
\hline & \multicolumn{4}{|c|}{ Dependent Variable_Fiscal_Space } \\
\hline & (1) & (2) & (3) & (4) \\
\hline L1_Fiscal_space & $\begin{array}{c}0.589462^{* * *} \\
(6.679095)\end{array}$ & $\begin{array}{c}0.978411^{* * *} \\
(18.17436)\end{array}$ & $\begin{array}{c}0.913110^{* * *} \\
(6.413059)\end{array}$ & $\begin{array}{c}0.8309177^{* * * *} \\
(6.241744)\end{array}$ \\
\hline Eng_TAX & $\begin{array}{c}22.59931 * * * \\
(7.410345)\end{array}$ & - & - & - \\
\hline Pol_TAX & - & $\begin{array}{c}0.976731 \\
(0.340777)\end{array}$ & - & - \\
\hline Res_TAX & - & - & $\begin{array}{c}3.042119 \\
(1.126639)\end{array}$ & - \\
\hline Tra_TAX & - & - & - & $\begin{array}{c}36.78904 * * * \\
(5.475574)\end{array}$ \\
\hline Control variables & \multicolumn{4}{|c|}{ Omit } \\
\hline
\end{tabular}


Table 4. Cont.

\begin{tabular}{|c|c|c|c|c|}
\hline \multirow{3}{*}{ Explanatory Variables } & \multicolumn{4}{|c|}{ Low Government Spending on the Environment } \\
\hline & \multicolumn{4}{|c|}{ Dependent Variable_Fiscal_space } \\
\hline & (1) & (2) & (3) & (4) \\
\hline L1_Fiscal_space & $\begin{array}{c}0.605624^{* * *} \\
(30.45575)\end{array}$ & $\begin{array}{c}0.722305^{* * *} \\
(25.40829)\end{array}$ & $\begin{array}{c}0.630372 * * * \\
(8.755745)\end{array}$ & $\begin{array}{c}0.607664^{* * *} \\
(39.08231)\end{array}$ \\
\hline Eng_TAX & $\begin{array}{c}27.69802^{* * *} \\
(6.911438)\end{array}$ & - & - & - \\
\hline Pol_TAX & - & $\begin{array}{c}-1.553725^{* *} \\
(-2.279094)\end{array}$ & - & - \\
\hline Res_TAX & - & - & $\begin{array}{c}3.831767 \\
(1.308519)\end{array}$ & - \\
\hline Tra_TAX & - & - & - & $\begin{array}{c}28.29003^{* * * *} \\
(4.836508)\end{array}$ \\
\hline Control variables & & & & \\
\hline
\end{tabular}

Source: Author's calculations using Eviews 11. Note: An explanation of research variables is provided in Table 2; t-statistic values in (). *** indicates the statistical significance at $1 \%$ level. ${ }^{* *}$ indicates the statistical significance at $5 \%$ level. * indicates the statistical significance at $10 \%$ level.

According to Eurostat, government environmental protection expenditure includes "transactions related to prevention, reduction and elimination of pollution and of any other degradation of the environment". For this part of the discussion of the research results, government spending on the environment is used as a proxy for environmental policy [69]. The EU member states are divided into two groups. The group with high government spending on the environment includes member states that annually spend on average more than $0.5 \%$ of their GDP on environmental issues. This first group includes Belgium, Croatia, the Czech Republic, Estonia, France, Greece, Hungary, the Netherlands, Romania, Slovakia, Spain, Sweden, and the UK. The other EU member states are included in the second group-low government spending in the environment. As previously mentioned, Malta is not included in this study due to lack of available data.

The results show that in countries with high levels of government spending on the environment, transport taxes would be the most effective environmental taxes in rebuilding fiscal space, while pollution taxes and resource taxes would not have any significant effect on fiscal space. For countries with low levels of government spending on the environment, energy taxes and transport taxes would be equally effective in helping regain fiscal space. However, increasing pollution taxes in these countries would have a detrimental effect on fiscal space according to the research results.

\subsection{Impact of Government Effectiveness}

Environmental taxes are essentially a type of government intervention in the economy included in the broader category of fiscal policy measures. Consequently, their effectiveness may be influenced by the taxpayer's perception of the effectiveness of the government. Existing literature $[70,71]$ shows an increase in voluntary conformity when taxpayers have a high level of trust in the government. Therefore, a discussion of our research results from this angle seems to be useful.

The four research models will be estimated again, taking government effectiveness into account. The results of these new estimations are presented in Table 5. The indicator used for government effectiveness is part of the Worldwide Governance Indicators calculated by the World Bank. It considers perceptions of the quality of public services and of policy formulation and implementation as well as the credibility of the government's commitment to such policies, with values ranging from -2.5 to 2.5 . Values for this indicator for the period 2011-2019 were collected, and an average was calculated for each country included 
in the study. It must be mentioned that the EU member states all have positive values for the government effectiveness indicator, with the sole exception of Romania, which has negative values for the indicator for the entire period considered.

Table 5. GMM estimation results for EU member states with different levels of government effectiveness.

\begin{tabular}{|c|c|c|c|c|}
\hline \multirow{3}{*}{ Explanatory Variables } & \multicolumn{4}{|c|}{ High Government Effectiveness } \\
\hline & \multicolumn{4}{|c|}{ Dependent Variable_Fiscal_Space } \\
\hline & (1) & (2) & (3) & (4) \\
\hline L1_Fiscal_space & $\begin{array}{c}0.810770 * * * \\
(24.87847)\end{array}$ & $\begin{array}{c}0.891529 * * * \\
(35.39949)\end{array}$ & $\begin{array}{c}0.758075^{* * *} \\
(32.34955)\end{array}$ & $\begin{array}{c}0.705180 * * * \\
(19.32509)\end{array}$ \\
\hline Eng_TAX & $\begin{array}{c}-8.221525 \\
(-1.657500)\end{array}$ & - & - & - \\
\hline Pol_TAX & - & $\begin{array}{c}4.556454 \text { *** } \\
(2.867967)\end{array}$ & - & - \\
\hline Res_TAX & - & - & $\begin{array}{c}0.729829 \\
(1.509122)\end{array}$ & - \\
\hline Tra_TAX & - & - & - & $\begin{array}{c}12.15420 \\
(1.290610)\end{array}$ \\
\hline Control variables & & & & \\
\hline \multirow{3}{*}{ Explanatory Variables } & \multicolumn{4}{|c|}{ Low Government Effectiveness } \\
\hline & \multicolumn{4}{|c|}{ Dependent Variable_Fiscal_Space } \\
\hline & (1) & (2) & (3) & (4) \\
\hline L1_Fiscal_space & $\begin{array}{c}-0.140971 \\
(-0.992803)\end{array}$ & $\begin{array}{c}0.387111 \\
(1.479257)\end{array}$ & $\begin{array}{l}0.270155^{* *} \\
(2.213081)\end{array}$ & $\begin{array}{c}-0.130543 \\
(-0.238291)\end{array}$ \\
\hline Eng_TAX & $\begin{array}{l}33.21212 * * \\
(2.403902)\end{array}$ & - & - & - \\
\hline Pol_TAX & - & $\begin{array}{c}3.686555 \\
(0.507202)\end{array}$ & - & - \\
\hline Res_TAX & - & - & $\begin{array}{l}3.283364 * \\
(1.660522)\end{array}$ & - \\
\hline Tra_TAX & - & - & - & $\begin{array}{l}65.95987^{*} \\
(1.968940)\end{array}$ \\
\hline
\end{tabular}

Source: Author's calculations using Eviews 11. Note: An explanation of research variables is provided in Table 2; t-statistic values in (). ${ }^{* * *}$ indicates the statistical significance at $1 \%$ level. ${ }^{* *}$ indicates the statistical significance at $5 \%$ level. ${ }^{*}$ indicates the statistical significance at $10 \%$ level.

The EU member states included in this study were split into two groups according to the average value of the government effectiveness indicator. The first group includes countries with high government effectiveness, which means an average indicator higher than 1. The member states included in the first group are Austria, Belgium, Cyprus, Denmark, Estonia, Finland, France, Germany, Ireland, Luxembourg, the Netherlands, Portugal, Slovenia, Spain, Sweden, and the UK. The other countries were put into group two-low government effectiveness.

The new estimation results show that for countries with high government effectiveness, the most useful environmental taxes to rebuild fiscal space are pollution taxes. For countries with low government effectiveness, energy taxes can be used as an effective tool to improve fiscal space. Additionally, the countries in the second group could also use transport taxes and resource taxes. Pollution taxes, however, would have no significant impact on fiscal space for these EU member states. 


\subsection{Robustness Check}

As a final part of the analysis of the research results, the robustness of the results was assessed. To achieve this, Generalized Linear Model (GLM) was used to estimate the same four regressions. The results are shown in Table 6.

Table 6. Estimation results using panel GLM.

\begin{tabular}{|c|c|c|c|c|}
\hline \multirow{2}{*}{ Explanatory Variables } & \multicolumn{4}{|c|}{ Dependent Variable_Fiscal_Space } \\
\hline & (1) & (2) & (3) & (4) \\
\hline L1_Fiscal_space & $\begin{array}{c}0.988874^{* * *} \\
(116.0318)\end{array}$ & $\begin{array}{c}0.995376^{* * *} \\
(136.3039)\end{array}$ & $\begin{array}{c}0.978687 \text { *** } \\
(116.8366)\end{array}$ & $\begin{array}{c}0.992617^{* * *} \\
(111.1951)\end{array}$ \\
\hline Eng_TAX & $\begin{array}{l}0.890787 \text { ** } \\
(2.343044)\end{array}$ & - & - & - \\
\hline Pol_TAX & - & $\begin{array}{c}0.557857 \text { *** } \\
(2.883944)\end{array}$ & - & - \\
\hline Res_TAX & - & - & $\begin{array}{c}1.092799 * * * \\
(3.670141)\end{array}$ & - \\
\hline Tra_TAX & - & - & - & $\begin{array}{c}0.798596^{* * *} \\
(2.684572)\end{array}$ \\
\hline PBY & $\begin{array}{c}0.683570 * * * \\
(6.429889)\end{array}$ & $\begin{array}{c}0.714512 * * * \\
(8.006804)\end{array}$ & $\begin{array}{c}0.813589 * * * \\
(8.470391)\end{array}$ & $\begin{array}{c}0.682700 * * * \\
(6.469578)\end{array}$ \\
\hline GDPG & $\begin{array}{c}0.731356^{* * * *} \\
(8.866180)\end{array}$ & $\begin{array}{c}0.745509 * * * \\
(10.66740)\end{array}$ & $\begin{array}{c}0.844505^{* * *} \\
(11.41184)\end{array}$ & $\begin{array}{c}0.733897 \text { *** } \\
(8.952355)\end{array}$ \\
\hline
\end{tabular}

Source: Author's calculations using Eviews 11. Note: An explanation of research variables is provided in Table 2; z-statistic values in (). ${ }^{* * *}$ indicates the statistical significance at $1 \%$ level. ${ }^{* *}$ indicates the statistical significance at $5 \%$ level. ${ }^{*}$ indicates the statistical significance at $10 \%$ level.

GLM was first put forward by Nedler and Wedderburn [72] at the beginning of the 1970s. For our robustness check, the estimated regression models are the ones previously described in Equations (2)-(5), and the results show great consistency with those obtained initially using GMM estimations.

\section{Conclusions}

The main focus of this paper was to analyze the potential use of environmental taxes in the European Union to regain the fiscal space lost due to increased government spending and borrowing in an effort to deal with the ongoing pandemic. To achieve this research goal, dynamic regression models were estimated using the Generalized Method of Moments, and the results were then reconfirmed using Generalized Linear Models. The results of the research show that all four types of environmental taxes have a positive, statistically significant effect on fiscal space, which allows us to answer the main research question in the affirmative.

The best outcome in terms of rebuilding fiscal space can be achieved by using energy taxes and transport taxes, but pollution taxes and resource taxes would also have a positive impact. These last two types of environmental taxes could be a good fiscal policy option for the EU member states that are not currently using them, such as Cyprus, Germany, Luxembourg, the Czech Republic, Greece, and Italy.

In addition to increasing tax revenues and, according to the current research results, improving fiscal space, environmental taxes have other benefits compared to other taxation measures: lower administrative costs, less potential for tax evasion, and diminished distortionary effect on economic behavior of the consumers. From a political point of view, most environmental taxes are indirect taxes, so stricter rules or increases in the tax base are unlikely to decrease a government's popularity among voters as would be the case for income taxes. 
The discussion of the research results based on specific country-based characteristics led to a few more conclusions regarding the use of environmental taxes in regaining fiscal space. On the one hand, in countries such as Belgium, Croatia, the Czech Republic, Estonia, France, Greece, Hungary, the Netherlands, Romania, Slovakia, and the UK, which have recorded high levels of government spending on the environment, the most effective category of environmental taxes in rebuilding fiscal space is transport taxes. On the other hand, in countries such as Austria, Denmark, Finland, France, Germany, Ireland, the Netherlands, Portugal, Slovenia, Spain, and Sweden, which have high government effectiveness, an effective climate-friendly fiscal policy solution to rebuild fiscal space is the use of pollution taxes.

The results of the current study confirm previously published research [26,41] as well as the research expectations regarding the control variables included in the analysis: the primary balance, economic growth, and average maturity of government debt. However, there is little research published on the idea of using environmental taxes to increase fiscal space, which constitutes both an opportunity for the current research to enhance the existing literature and a limitation, as these research results cannot thoroughly be compared to previous ones.

The current study could be helpful to both policymakers and the academic world. Government decision makers should use the results included in this research to look at a possible new solution to the current problem of regaining fiscal space in the EU. For the academic world, the current research provides a fresh approach to determining fiscal space and a hopefully valuable addition to the research conducted on environmental taxes, debt sustainability, and improving fiscal space.

All in all, the governments of the EU member states can use environmental taxes to help them rebuild fiscal space lost in the battle with the COVID-19 pandemic.

Funding: This research received no external funding.

Institutional Review Board Statement: Not applicable.

Informed Consent Statement: Not applicable.

Data Availability Statement: Not applicable.

Conflicts of Interest: The author declares no conflict of interest.

\section{References}

1. Eurostat. Environmental Tax Statistics. 2021. Available online: https:/ / ec.europa.eu/eurostat/statistics-explained/index.php/ Environmental_tax_statistics (accessed on 6 February 2021).

2. Alesina, A.; Favero, C.; Giavazzi, F. Effects of Austerity: Expenditure- and Tax-based Approaches. J. Econ. Perspect. 2019, 33, 141-162. [CrossRef]

3. Zito, A.R.; Burns, C.; Lenschow, A. Is the trajectory of European Union environmental policy less certain? Environ. Polit. 2019, 28, 187-207. [CrossRef]

4. Newbery, D.M. Harmonizing Energy Taxes in the EU. In Proceedings of the Tax Policy in the European Union, The Hague, The Netherlands, 17-19 October 2001.

5. Sterner, T.; Köhlin, G. Environmental Taxes in Europe. Environ. Tax. Pract. 2017, 3, 3-28. [CrossRef]

6. Hodžić, S.; Bratić, V. Comparative Analysis of Environmental Taxes in EU and Croatia. Ekon. Misao I Praksa $2015,2,555-578$.

7. Selin, H.; VanDeveer, S.D. European Union and Environmental Governance, 1st ed.; Routledge: New York, NY, USA, 2015 ; pp. 6-51.

8. Speck, S.; Paleari, S. Environmental Taxation and EU Environmental Policies; Report no. 16; European Environment Agency: Copenhagen, Denmark, 2016; Available online: https:/ /www.eea.europa.eu/publications/environmental-taxation-and-euenvironmental-policies (accessed on 14 December 2020).

9. Parry, I.W.; Norregaard, J.; Heine, D. Environmental Tax Reform: Principles from Theory and Practice to Date. IMF Work. Pap. 2012, 12. [CrossRef]

10. Fullerton, D.; Leicester, A.; Smith, S. Environmental Taxes. In Dimensions of Tax Design—The Mirrlees Review; Mirrlees, J., Ed.; Oxford University Press: Oxford, UK, 2010; pp. 423-547. Available online: https://www.ifs.org.uk/uploads/mirrleesreview/ dimensions / ch5.pdf (accessed on 7 December 2020).

11. Andreoni, V. Environmental taxes: Drivers behind the revenue collected. J. Clean. Prod. 2019, 221, 17-26. [CrossRef]

12. Borozan, D. Efficiency of Energy Taxes and the Validity of the Residential Electricity Environmental Kuznets Curve in the European Union. Sustainability 2018, 10, 2464. [CrossRef] 
13. Moutinho, V.; Madaleno, M.; Robaina, M. The economic and environmental efficiency assessment in EU cross-country: Evi-dence from DEA and quantile regression approach. Ecol. Indic. 2017, 78, 85-97. [CrossRef]

14. Gao, X.; Zheng, H.; Zhang, Y.; Golsanami, N. Tax Policy, Environmental Concern and Level of Emission Reduction. Sustainability 2019, 11, 1047. [CrossRef]

15. Vallés-Giménez, J.; Zárate-Marco, A. A Dynamic Spatial Panel of Subnational GHG Emissions: Environmental Effectiveness of Emissions Taxes in Spanish Regions. Sustainability 2020, 12, 2872. [CrossRef]

16. Mannberg, A.; Jansson, J.; Pettersson, T.; Brännlund, R.; Lindgren, U. Do tax incentives affect households' adoption of 'green' cars? A panel study of the Stockholm congestion tax. Energy Policy 2014, 74, 286-299. [CrossRef]

17. Kok, R. Six years of CO2-based tax incentives for new passenger cars in The Netherlands: Impacts on purchasing behavior trends and CO2 effectiveness. Transp. Res. Part A Policy Pract. 2015, 77, 137-153. [CrossRef]

18. Alonso, S.L.N. The Tax Incentives in the IVTM and "Eco-Friendly Cars": The Spanish Case. Sustainability 2020, 12, 3398. [CrossRef]

19. Scott, M.; Van Huizen, J.; Jung, C. The Bank of England's Response to Climate Change. Bank Engl. Q. Bull. 2017, Q2, 98-109.

20. Dafermos, Y.; Nikolaidi, M.; Galanis, G. Climate Change, Financial Stability and Monetary Policy. Ecol. Econ. 2018, 152, 219-234. [CrossRef]

21. Catalano, M.; Forni, L.; Pezzolla, E. Climate-change adaptation: The role of fiscal policy. Resour. Energy Econ. $2020,59,101111$. [CrossRef]

22. Aizenman, J.; Hutchison, M.; Jinjarak, Y. What is the risk of European sovereign debt defaults? Fiscal space, CDS spreads and market pricing of risk. J. Int. Money Finance 2013, 34, 37-59. [CrossRef]

23. Onofrei, M.; Bostan, I.; Oprea, F.; Paraschiv, G.; Lazăr, C.M. The Implication of Fiscal Principles and Rules on Promoting Sustainable Public Finances in the EU Countries. Sustainability 2020, 12, 2772. [CrossRef]

24. Lozano-Espitia, I.; Julio-Román, J.M. Debt limits and fiscal space for some Latin American economies. Lat. Am. J. Central Bank. 2020, 1, 100006. [CrossRef]

25. Estevão, M. Climate-Smart Fiscal Policy Can Foster a Lasting Economic Recovery. One Earth 2020, 3, 273-276. [CrossRef]

26. Heller, P. Understanding Fiscal Space; IMF Policy Discussion Paper No. PDP/05/4; International Monetary Fund: Washington, DC, USA, 2005.

27. Schick, A. Budgeting for fiscal space. OECD J. Budg. 2009, 9, 1-18. [CrossRef]

28. Roy, R.; Heuty, A.; Letouzé, E. Fiscal space for what? Analytical issues from a human development perspective. In Proceedings of the Paper for the G20-Workshop on Fiscal Policy, UNDP, New York, NY, USA, 30 June-2 July 2007.

29. Ostry, J.; Ghosh, A.R.; Kim, J.I.; Qureshi, M. Fiscal Space; IMF Staff Position Note SPN/10/11; International Monetary Fund: Washington, DC, USA, 2010.

30. Ghosh, A.; Kim, J.; Mendoza, E.; Ostry, J.; Qureshi, M. Fiscal Fatigue, Fiscal Space and Debt Sustainability in Advanced Economies. Econ. J. 2011, 123, 4. [CrossRef]

31. Blanchard, O.; Chouraqui, J.C.; Hagemann, R.; Sartor, N. The sustainability of fiscal policy: New answers to an old questions. OECD Econ. Stud. 1990, 15, 7-36.

32. Fournier, J.-M.; Fall, F. Limits to government debt sustainability in OECD countries. Econ. Model. 2017, 66, 30-41. [CrossRef]

33. Botev, J.; Fournier, J.-M.; Mourougane, A. A Re-assessment of Fiscal Space in OECD Countries. OECD Econ. Dep. Work. Pap. 2016. [CrossRef]

34. Saxegaard, M. Safe Debt and Uncertainty in Emerging Markets: An Application to South Africa. IMF Work. Pap. 2014, 14, 1. [CrossRef]

35. Adedeji, O.; Ahokpossi, C.; Battiati, C.; Farid, M. A Probabilistic Approach to Fiscal Space and Prudent Debt Level: Application to Low-Income Developing Countries. IMF Work. Pap. 2016, 16, 1. [CrossRef]

36. Park, S. Quantifying Impact of Aging Population on Fiscal Space; IMF Working Paper No. 12/164; International Monetary Fund: Washington, DC, USA, 2012.

37. Mario, M. Budgeting for fiscal space and government performance beyond the great recession. OECD J. Budg. $2013,13,9-47$.

38. Aizenman, J.; Jinjarak, Y. De facto Fiscal Space and Fiscal Stimulus: Definition and Assessment. De Facto Fiscal Space Fiscal Stimul. Defin. Assess. 2010. [CrossRef]

39. Aizenman, J.; Jinjarak, Y.; Nguyen, H.T.K.; Park, D. Fiscal space and government-spending and tax-rate cyclicality patterns: A cross-country comparison, 1960-2016. J. Macroecon. 2019, 60, 229-252. [CrossRef]

40. Gnangnon, S.K. Export product concentration and De Facto Fiscal Space: Does openness to international trade matter? Glob. Econ. J. 2018, 18, 1-12. [CrossRef]

41. Gnangnon, S.K.; Brun, J.-F. Tax reform and fiscal space in developing countries. Eurasian Econ. Rev. 2019, 10, 237-265. [CrossRef]

42. Yohou, D.H. In Search of Fiscal Space in Africa: The Role of the Quality of Government Spending; CERDI, Série Études Et Documents: Clermont-Ferrand, France, 2015; p. 27.

43. Kose, M.A.; Kurlat, S.; Ohnsorge, F.; Sugawara, N. A Cross-Country Database of Fiscal Space. World Bank Policy Research Working Paper 8157, 2020 update, World Bank, Washington, DC. Available online: https:/ /openknowledge.worldbank.org/ handle/10986/27964 (accessed on 10 December 2020).

44. Bai, J.; Lu, J.; Li, S. Fiscal Pressure, Tax Competition and Environmental Pollution. Environ. Resour. Econ. 2018, 73, 431-447. [CrossRef]

45. Kaiser, H.F. An index of factorial simplicity. Psychometrike 1974, 39, 31-36. [CrossRef] 
46. Tabachnick, B.G.; Fidell, L.S. Using Multivariate Statistics, 7th ed.; Pearson: New York, NY, USA, 2019 ; pp. $476-511$.

47. Hair, J.F.; Black, W.C.; Babin, B.J.; Anderson, R.E. Multivariate Data Analysis, 7th ed.; Pearson Education Limited: Harlow, UK, 2013.

48. Nerlich, C.; Reuter, W. The Design of National Fiscal Frameworks and Their Budgetary Impact. ECB Working Paper Series No. 1588. 2013, pp. 1-30. Available online: https://www.ecb.europa.eu/pub/pdf/scpwps/ecbwp1588.pdf (accessed on 1 January 2021).

49. Izák, V. Primary balance, public debt and fiscal variables in postsocialist members of the european union. Prague Econ. Pap. 2009, 18, 114-130. [CrossRef]

50. Beqiraj, E.; Fedeli, S.; Forte, F. Public debt sustainability: An empirical study on OECD countries. J. Macroecon. 2018, 58, 238-248. [CrossRef]

51. Tandon, A.; Cashin, C. Assessing Public Expenditure on Health from a Fiscal Space Perspective. World Bank Health. Nutrition and Population (HNP) Discussion Paper 2010, 56053. Available online: https://openknowledge.worldbank.org/bitstream/ handle/10986/13613/560530WP0Box341penditureFiscalSpace.pdf?sequence=1\&isAllowed=y (accessed on 10 December 2020).

52. Okwero, P.; Tandon, A.; Sparkes, S.; McLaughlin, J.; Hoogeveen, J.G. Fiscal Space for Health in Uganda. World Bank Working Paper No. 186. 2010. Africa Human Development Series. Available online: https:/ / openknowledge.worldbank.org/handle/10 986/5949 (accessed on 7 January 2021).

53. Alagidede, P.; Mensah, J.O.; Ibrahim, M. Optimal Deficit Financing in a Constrained Fiscal Space in Ghana. Afr. Dev. Rev. 2018, 30, 291-303. [CrossRef]

54. Kim, J.I.; Ostry, J.D. Boosting Fiscal Space: The Roles of GDP-Linked Debt and Longer Maturities. Econ. Policy 2021, 024. [CrossRef]

55. Arellano, M.; Bond, S. Some tests of specification for panel data: Monte Carlo evidence and an application to employment equations. Rev. Econ. Stud. 1991, 58, 277-297. [CrossRef]

56. Arellano, M.; Bover, O. Another look at the instrumental variable estimation of error-components models. J. Econ. 1995, 68, 29-51. [CrossRef]

57. Blundell, R.; Bond, S. Initial conditions and moment restrictions in dynamic panel data models. J. Econ. 1998, 87, 115-143. [CrossRef]

58. Roodman, D. How to do Xtabond2: An Introduction to Difference and System GMM in Stata. Stata J. Promot. Commun. Stat. Stata 2009, 9, 86-136. [CrossRef]

59. Briceño, H.R.; Perote, J. Determinants of the Public Debt in the Eurozone and Its Sustainability Amid the Covid-19 Pandemic. Sustainability 2020, 12, 6456. [CrossRef]

60. European Commission. Economic and Financial Affairs. Autumn 2020 Economic Forecast. Available online: https://ec.europa. eu/info/sites/info/files/economy-finance/ip136_en_2.pdf (accessed on 12 December 2020).

61. Arellano, C.; Bai, Y.; Mihalache, G. Deadly Debt Crises: COVID-19 in Emerging Markets. 2020 National Bureau of Economic Research Working Paper Series No. 27275. Available online: https:/ /www.nber.org/papers/w27275 (accessed on 1 April 2021).

62. Peterson, K.O. The COVID-19 Global Debt Crisis: How to Avoid It. Global Economics Science 2021. Available online: https: / / papers.ssrn.com/sol3/papers.cfm?abstract_id=3819071 (accessed on 2 April 2021).

63. Sargan, J.D. The Estimation of Economic Relationships using Instrumental Variables. Econ. Soc. 1958, 26, 393. [CrossRef]

64. Hansen, L.P. Large Sample Properties of Generalized Method of Moments Estimators. Econ. Soc. 1982, 50, 1029. [CrossRef]

65. Rapanos, V.T.; Polemis, M.L. Energy demand and environmental taxes: The case of Greece. Energy Policy 2005, 33, 1781-1788. [CrossRef]

66. Morley, B. Empirical evidence on the effectiveness of environmental taxes. Appl. Econ. Lett. 2012, 19, 1817-1820. [CrossRef]

67. Hájek, M.; Zimmermannová, J.; Helman, K.; Rozenský, L. Analysis of carbon tax efficiency in energy industries of selected EU countries. Energy Policy 2019, 134, 110955. [CrossRef]

68. Niu, T.; Yao, X.; Shao, S.; Li, D.; Wang, W. Environmental tax shocks and carbon emissions: An estimated DSGE model. Struct. Chang. Econ. Dyn. 2018, 47, 9-17. [CrossRef]

69. Ercolano, S.; Romano, O. Spending for the Environment: General Government Expenditure Trends in Europe. Soc. Indic. Res. 2018, 138, 1145-1169. [CrossRef]

70. Gribnau, H.J.; Jallai, A.-G. Good Tax Governance: A Matter of Moral Responsibility and Transparency. Nord. Tax J. 2017, 2017, 70-88. [CrossRef]

71. Torgler, B. Tax Morale, Rule-Governed Behaviour and Trust. Const. Political Econ. 2003, 14, 119-140. [CrossRef]

72. Nelder, J.A.; Wedderburn, R.W.M. Generalized Linear Models. J. R. Stat. Soc. 1972, 135, 370-384. [CrossRef] 